\title{
CHALLENGE STRESSORS AS A MOTIVATIONAL TOOL: FEMALE EMPLOYEES IN THE MONGOLIAN BANKING SECTOR
}

\author{
Tumentsetseg Enkhjav \\ Szent Istvan University, Hungary \\ Csehné Papp Imola \\ Eötvös Loránd University, Hungary \\ Erika Varga \\ Szent Istvan University, Hungary
}

\begin{abstract}
This study examines whether challenge stressors can be one of the root causes of burnout among Mongolian female employees in the banking sector. The service industry contributes to more than 50 percent of GDP in Mongolia, and most employees in the financial sector are females. The adaption of smart technologies in this sector is thriving. Therefore, the first objective was to reveal whether there is a significant relationship between challenge stressors and burnout. The second objective was to test whether challenge stressors are inversely related to burnout and its three dimensions. A quantitative design was applied, and 101 validated questionnaires were analyzed. Overall, approximately $4 \%$ of the variance in burnout can be predicted by challenge stressors. HR professionals who are in charge of the retention programs in the banking sector are advised to be well aware of how to manage the challenge stressors.
\end{abstract}

Keywords: challenge stressors, burnout, emotional exhaustion, depersonalization, personal accomplishment, Mongolia

DOI: http://dx.doi.org/10.15549/jeecar.v7i3.451

\section{INTRODUCTION}

Background of the study

Globally, the female population seems to be slightly larger than the male population in some countries. Mongolia is one of the typical examples representing the gender ratio of $49.1 \%$ men and $50.8 \%$ women in 2020. (National Statistical Office of Mongolia [NSOM], 2020). The female labor participation (FLP) rate in Mongolia has always been higher at over 50\% and above the world average since 1990 (Figure 
1). About $80 \%$ of employees in Mongolia's financial sector are dominated by females (NSOM, 2019). In fact, women's leadership (Millier, \& Bellamy, 2014) and FLP in Asian countries have been emphasized by many studies around the world. However, when it comes to Mongolia's case, a very limited number of studies have been investigated covering the workplace-related stress among females. From a practical point of view, it is obvious that handling their continuous chores at home and performing their jobs well at the same time can be sources of stressors that may drive more stress in women at work. Some studies have stated that stress is somehow higher among females than males (Cohen \& Janicki-Deverts, 2012; Kessler et al., 1985).
Also, Jex (1988) reported that stressors are root causes of strains including depression, exhaustion, and burnout. If the stress triggers burnout, it may be worth investigating the relationship between challenge stress and burnout since challenge and hindrance stressors can have a certain influence on employees' outcomes (Podsakoff, 2007). Also, positive job stress found to be positively related to satisfaction with work, organizational commitment (Bhagat et al., 1985; Scheck et al., 1995; Cavanaugh et al., 2000; Boswell, et al., 2004; Bingham et al., 2005; Podsakoff et al., 2007), motivation and performance (LePine et al., 2005).

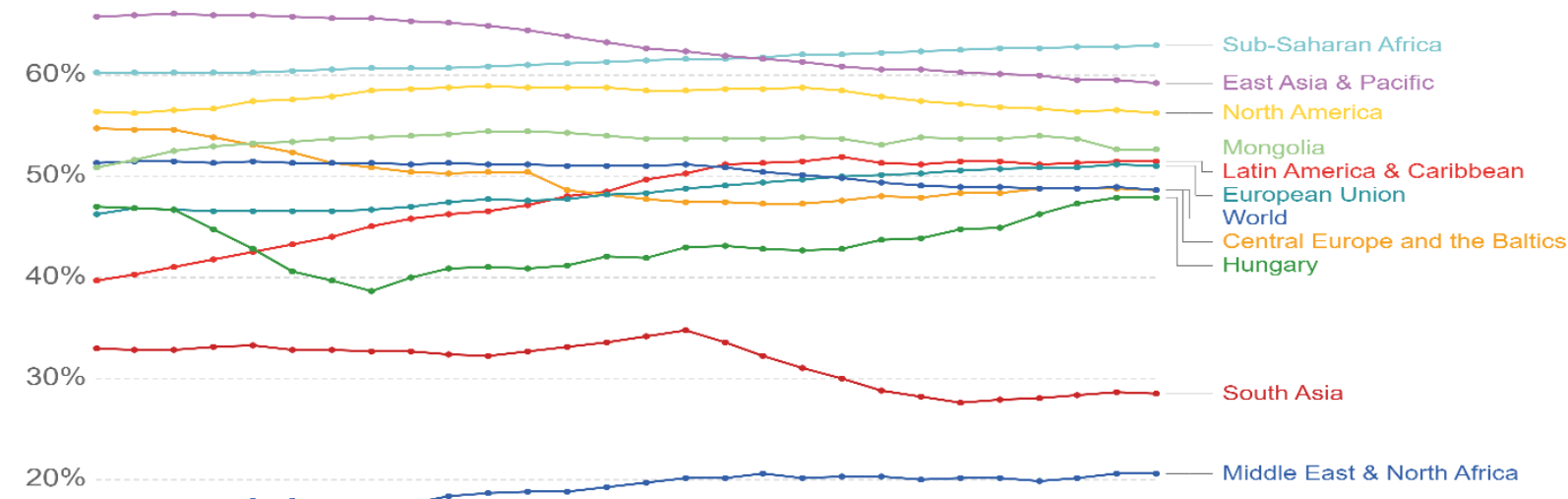

$10 \%$

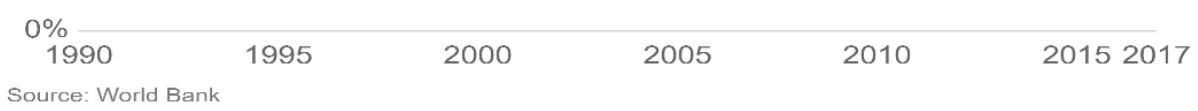

CC BY-SA

Figure 1. Female Labor Force Participation Rate

Source: Our World in Data, 2017

Although the work-related stressors are recently differentiated into two different categories - challenge and hindrance stressorsin the study of Cavanaugh et al., (2000); Boswell et al., (2004) and Bringham et al., (2005), examining the effects of stressors at workplaces, however, not all stressors in the workplace were observed to have some negative effects on employees attitudes as well as on their performance outcomes by some researchers (Bhagat et al., 1985; Sarason, \&
Johnson, 1979; Scheck et al., 1995; 1997) in the early literature. According to LePine et al., (2005), the challenge stressors are defined as positive work demands such as time pressures, workload, job responsibility, and job complexity - have a positive association with employee strains, motivation, and performance. Most importantly, the studies were conducted in the category of positive job stressors found that challenge-related job demands are negatively related to job search (Cavanaugh et 
al., 2000; Boswell et al., 2004), intentions to leave, and turnover (Podsakoff et al., 2007).

It has become more and more difficult for service providers to provide an unforgettable and unique experience in order to keep attracting more customers and making them loyal clients (Chathoth et al., 2013), which may make employees get stressed as well as burnout in the service industry (Behrman \& Perrault, 1984; Yagil, 2008). In other words, the constant interaction with customers (Behrman \& Perreault, 1984) and task repetition (Taylor \& Bain, 1999) may promote an increase in burnout's feelings at the workplace. It is a common practice that service-oriented organizations require employees to obey their behavior standards and regulations in order to achieve organizational purposes (Diefendorff et al., 2006). It is so-called emotional labor, and its association with burnout has been confirmed by many studies in the literature such as Kruml and Greddes, (2000), Brotheridge and Grandey, (2002); Zapf (2002); and Kim (2008). Therefore, it may be a common phenomenon for employees in the service industry to reach burnout because of the job they perform.

Mongolia's service industry plays a significant role in its economy and contributes to $50.7 \%$ of GDP (NSOM, 2019).

The technological revolution has been gradually changing the course of the financial industry and is not only driving Fintech but it is also influencing the basic forms of many financing services in the banking sector regarding the concept of big data, artificial intelligence, value chain, and blockchain. Scholars generally recommend that companies have to keep up the main flows of technological changes on time to stay in competition on the market (Wang et al., 2015). The impact of technological revolutions on the financial as well as all other industries requires employees to acquire a certain kind of technical and nontechnical skills (Janis \& Alias, 2017; Veresné Valentinyi, 2015). Therefore, reinventing and adapting oneself to the rapidly changing workplace generates another root cause of workplace stress that may make employees emotionally exhausted.

\section{Problem statement}

Surveys conducted over the last four decades indicate that half to three- quarters of today's workforce describe their work as very stressful (Greenberg \& Canzeroni, 1996). Unfortunately, this trend is expected to continue due to rapidly developing technological changes, economic crises, and environmental problems all around the world. For female employees who work in the service industry may get stressed more than those who are employed in different sectors because of emotional labor as well as their household responsibilities at home. Also, human beings are at the transaction stage of the technological revolution and nobody is able to predict how future workplaces will look like and how many of us are going to be replaced by robots and machines by 2050 . We can be sure the change is happening, and we are witnessing it at every walk of our life nowadays. However, according to literature, some stressors are acknowledged to be positive, promoting employees to enhance their careers, getting satisfied with work (Sarason \& Jonhson, 1979; Scheck et al., 1995; Cavanaugh et al., 2000; Boswell et al., 2004; Bringham et al., 2005), demonstrating a commitment to their organizations (Bhagat et al., 1985; Podsakoff et al., 2007), staying motivated, and delivering better performance at work (LePine et al., 2005). Therefore, keeping this overall picture in mind, the researchers upheld the strong desire to find out how female employees in Mongolia's banking sector feel about challenge stressors at work.

\section{Purpose of the study}

Generally, this study aims to examine what kind of relationship exists between the challenges stressors and burnout among female employees in the banking sector in Mongolia.

\section{Research Questions}

The followed research questions have been developed in order to achieve the purpose of this study.

1. Are challenges stressors negatively associated with Burnout among Mongolian female bank workers? 
2. Are the challenge stressors a significant predictor of burnout among female employees in the banking sector in Mongolia?

\section{LITERATURE REVIEW}

\section{Background of Mongolia}

Mongolia is a country of nearly 3.1 million inhabitants, and is estimated to be one of the 3G (Global Growth Generators) nations which is predicted to achieve high growth and yield profitable investment opportunities over the next 30 years due to its growing young generation and natural resources (Buiter \& Rahbar, 2011). More specifically, about 1.5 million males and 1.6 million females are officially counted in a demographical statistic report of February 2019.

Officially 636.874 individuals are employed by 33.899 firms in the service industry in 2019 ([NSOM], 2019). In addition, the financial and insurance sectors employ about 22.216 people, and the majority of them (70.9\%) are females who serve in this industry as of March 2019.

\section{The financial industry and banking sector in Mongolia}

At the end of 2018, 14 commercial banks were operating with the human capital of 15.000 employees through 1516 branches in Mongolia. About 938,000 bank borrowers and 9.1 million customers throughout the whole country received financial service by using offline and online services. From 2009 to 2014, the banking sector in Mongolia has consistently occupied around 95\% of the total financial market asset (Davaasuren, 2015).

Despite the traditional financial system, the advancement of information and communication technology is reshaping the financial industry around the world by offering various types of online payments, transactions, savings, loans, and insurance services - it is socalled Fintech. In Mongolia, several Fintech companies such as LendMN, Ard Credit, and Hipay offer different financial services and have already extended their market abroad (Jargalsaikhan, 2019). Nowadays, many new initiatives and changes from the revolution in information and communication technology are being generated in the financial sector in Mongolia, but a very limited number of studies have been carried out regarding HR issues of the financial industry in Mongolia.

\section{Challenge stressors}

Today's workplace is becoming more and more competitive and stressful than ever before due to the revolution's effects on information and communication technology and many other factors. It is generally agreed that machine learning and robotics will change every line of work (Harari, 2018). According to Frey and Osborne (2013), approximately 47\% of jobs in the USA and $54 \%$ in Europe will disappear due to automation. Therefore, it is not arguable any longer that employees are demanding more technical related competencies of tomorrow's workplaces (Golightly et al., 2016; Neugebauer et al., 2016; Yu et al., 2015). For employers, about $80 \%$ of them expect their employees to adapt and gain new skills in order to fit into their jobs in the future (World Economic Forum, 2018). Besides, companies in the service industry like the banking sector urge their staff to utilize emotional labor. As a result, many employees need to control their emotions and act according to a company's standard requirements, which may push them to get burnout at the workplace because being in a constant state of emotional labor may cause emotional exhaustion among employees (Hochschild, 1983).

In the case of female employees, they may be more stressed due to maternal health, fertility, childcare, and other family-oriented policies, labor-saving consumer durables, social norms and culture, and structural changes in the economy (Our World in Data, 2017). For instance, Marshall and Tracy (2009) and Marshall and Barnet (1993) highlighted the findings of the study that the work-family conflict is being pervasive among female workers who have an infant. In response to these circumstances, female employees may get more stressed and depressed in the workplace in many cases. However, certain kinds of stressors are found to be job demands that promote employee's personal growth and development at work (Cavanaugh et al., 2000). 


\section{Job burnout}

Job burnout is defined as a syndrome that is composed of three dimensions, including emotional exhaustion, depersonalization, and personal accomplishment (Maslach \& Jackson, 1981; Maslack et al., 2001).

Emotional exhaustion is a depleted feeling of mental and emotional tiredness due to the execution of daily work activities, but it continues affecting them throughout the day.

Depersonalization implies that negative or pessimistic attitudes and characteristics that workers demonstrate to the clients in any industry. Moreover, it causes more harmful effects on the service industry since more proactive and respectful interactions are always prioritized.

Personal accomplishment is one's reduced accomplishment which represents the selfevaluation dimension of burnout. It means that people directly feel incompetent, unsuccessful, and demotivated when their performance is revealed as poorer than their colleagues at work, which causes dysfunctional attitudes, low performance, and personal ineffectiveness for employees (Maslach \& Jackson, 1981). Therefore, burnout is manifested by workers when employees perceive difficulties to meet organizational expectations (Hobfoll \& Shirom, 2000).

A review article was conducted by Purvanova and Muros (2010) based on the 1833 studies on three dimensions of burnout showed that female employees were more likely to be emotionally exhausted than male employees.

\section{The relationship between Challenge stressors and burnout}

The service industry sells various products and services using intensive and proactive communication tools between employees and customers. Almost all types of employees in the banking sector have to have specific interactions with customers in a particular circumstance. This intensive and constant interaction is more likely to produce certain work-related stress among employees (Behrman \& Perreault, 1984). More broadly, this kind of stress happens when employees consume too many emotional resources to sell a product by interacting with different types of customers on a daily basis (Cordes \& Dougherty, 1993). According to Taylor and Bain (1999), task repetition and monotonous activities can cause stress during employeecustomer interaction in the service industry, which might increase the feeling of burnout. Zapf et al. (1999) assert that there is an association between emotional labor and emotional exhaustion.

Stress has become a very popular topic among scholars. However, recently, researchers have found that challenge stressors have negative associations with job search (Cavanaugh et al., 2000), turnover (Boswell et al., 2004), and intentions to leave an organization (Podsakoff et al., 2007). Moreover, according to LePine et al., (2005), managers may be able to motivate their staffs, and to improve their performance by increasing challenge stressors because challenge stressors have a positive relationship with satisfaction, motivation, organizational commitment as well as employees' performance (Bringam et al., 2005; Scheck et al., 1995). Therefore, the following hypotheses on the relationship between challenge stressors and burnout were built to examine in this study.

$\mathrm{H} 1$ : There is a relationship between challenge stressors and burnout.

$\mathrm{H} 2$ : Challenge stressors are negatively related to burnout.

H2a Challenge stressors are negatively related to emotional exhaustion

$\mathrm{H} 2 \mathrm{~b}$ Challenge stressors are negatively related to depersonalization

$\mathrm{H} 2 \mathrm{c}$ Challenge stressors are negatively related to personal accomplishment

\section{METHODOLOGY}

The quantitative research design was employed. A self-administered and online questionnaire was created using the Google survey platform to collect data from 101 female bank workers from January to April 2019.

35 previously validated items were chosen to measure challenge stressors (6) using the scales created by Rodell and Judge (2009) based on 
prior validated scales from (Cavanaugh et al., 2000; Ivancevich \& Matteson, 1980), and burnout (22) was measured using the scale originated by Maslach, et al., (1996). A 6- and 5point Likert rating scales were implemented. A translation validation process was conducted. Snowball and convenience sampling methods were applied, and SPSS 20.0 was performed to analyze the compiled data.

\section{RESULTS}

\section{Descriptive Analysis}

Approximately $93 \%$ of the participants belong to two different age categories between $18-30$ and 31-40. Among them, 65\% are married. The majority of them (58\%) have two children. Regarding the salary level, half of them have indicated that their monthly salary ranges between $\$ 192$ and $\$ 384$. Most of them (45\%) have 1 to 5 years of working experience, whereas $37 \%$ have 3 to 5 years of career seniority. For the educational level, most surveyed participants (80\%) hold a bachelor's degree while $17 \%$ have a master's degree.

\section{Validity and Reliability}

The reliability analysis results generated the Cronbach alpha's values of the three sub- dimensions of burnout and challenge stressors that were higher than .70 (ranging from .70 for burnout and .84 for challenge stressors).

\section{Correlation Analysis}

According to the correlation analysis results, as shown in Table 1, there is a statistically significant positive relationship between challenge stressors and burnout $(\mathrm{r}=.208, \mathrm{p}<.05)$. The relationship between challenge stressors and three sub-dimensions of burnout, emotional exhaustion, and depersonalization that have a statistically significant association with challenge stressors $(\mathrm{r}=.339, \mathrm{p}<.01$, and $\mathrm{r}=.268, \mathrm{p}<.01$ respectively) were also examined. More interestingly, their correlation values were found positive. For personal accomplishment, that is only one subdimension with a negative and significant correlation with challenge stressors $(\mathrm{r}=-.233$, $\mathrm{p}<.01$ ). However, Hypothesis $2 \mathrm{c}$ was accepted. Notably, the correlation analysis result also demonstrates that that number of children is negatively correlated with burnout $(\mathrm{r}=-.207$. $\mathrm{p}<.05$ ), and emotional exhaustion which is negatively related to age $(\mathrm{r}=-.212, \mathrm{p}<.05)$, marital status $(\mathrm{r}=-.233, \mathrm{p}<.05)$, number of children $(\mathrm{r}=-.281, \mathrm{p}<.05)$ and career seniority $(\mathrm{r}=-.215, \mathrm{p}<.05)$.

Table 1. The Result of Pearson's Correlation Analysis

\begin{tabular}{|c|c|c|c|c|c|c|c|c|c|c|c|c|}
\hline & Variables & 1 & 2 & 3 & 4 & 5 & 6 & 7 & 8 & 9 & 10 & 11 \\
\hline 1 & Burnout & & & & & & & & & & & \\
\hline 2 & $\mathrm{CS}$ & $.208^{*}$ & & & & & & & & & & \\
\hline & Emotional & $.761^{* *}$ & $.339^{* \prime}$ & & & & & & & & & \\
\hline 3 & exhaustion & & & & & & & & & & & \\
\hline 4 & Depersonalization & $.719^{* *}$ & $.268^{* *}$ & $.613^{* *}$ & & & & & & & & \\
\hline & Personal & $.279^{* *}$ & - & $-.300^{* *}$ & $-.254^{*}$ & & & & & & & \\
\hline 5 & accomplishment & & $.233^{*}$ & & & & & & & & & \\
\hline 6 & Age & -.188 & -.101 & $-.212^{*}$ & -.187 & .063 & & & & & & \\
\hline 7 & Educational level & .011 & .027 & .032 & -.024 & .002 & .104 & -.048 & .049 & $.300^{* *}$ & -.133 & .121 \\
\hline
\end{tabular}

Source: Authors' own editing

\section{Simple linear regression analysis}

According to the result of the regression, a significant and positive regression equation model was found $(F(1,99)=4.488$. $\mathrm{p}<0.05)$, with an $R^{2}$ of .043 . The burnout increased .387 units for each unit of challenge stressors. In other words, challenge stressors are a statistically significant predictor of burnout 
$(\beta=.208,<0.05)$. Challenge stressors can predict $4 \%$ of the variance in burnout. After a significant and positive regression equation was found in the model of challenge stressors and burnout, researchers run a single linear regression analysis between challenge stressors and three dimensions of burnout (emotional exhaustion, depersonalization, and personal accomplishment) in order to ascertain how many percent of burnout can be predicted by each dimension of burnout. The result of regression analyses, shown in Table 3 indicates that challenge stressors are a statistically positive and significant predictor of two dimensions of burnout, namely, emotional exhaustion and depersonalization $(\beta=.268, \mathrm{p}<0.01 ; \beta=.339, \mathrm{p}<$ 0.001 respectively). Challenge stressors can predict $7 \%$ of the variance in emotional exhaustion and $11 \%$ of the variance in depersonalization. Also, Table 3 shows that challenge stressors are a statistically negative and significant predictor of personal accomplishment (challenge stressors predict $\beta=$ $-.233, \quad \mathrm{p}<0.05)$, and $5 \%$ of personal accomplishment.

Table 2. The Linear Regression Results for the Relationship between Challenge Stressors and Burnout

\begin{tabular}{|c|c|c|c|c|c|c|c|}
\hline \multirow[b]{2}{*}{ Model } & \multicolumn{2}{|c|}{$\begin{array}{l}\text { Unstandardized } \\
\text { Coefficients }\end{array}$} & \multirow{2}{*}{$\begin{array}{c}\text { Standardized } \\
\text { Coefficients } \\
\text { Beta } \\
\end{array}$} & \multirow[t]{2}{*}{ Sig. } & \multirow[t]{2}{*}{$F$} & \multirow[t]{2}{*}{ Sig. } & \multirow[t]{2}{*}{$R 2$} \\
\hline & B & $\begin{array}{r}\text { Std. } \\
\text { Error }\end{array}$ & & & & & \\
\hline (Constant) & 71.615 & 3.016 & & $\begin{array}{l}.00 \\
0\end{array}$ & & & \\
\hline $\begin{array}{l}\text { Challenge } \\
\text { Stressors }\end{array}$ & .387 & .183 & $.208^{* *}$ & $\begin{array}{l}.03 \\
7\end{array}$ & $4.488^{*}$ & .037 & .043 \\
\hline
\end{tabular}

Note. Dependent Variable: Burnout

${ }^{*} p<.05,{ }^{* *} p<.01,{ }^{* * *} p<.001$

Table 3. The Linear Regression Results for the Relationship between Challenge stressors and Emotional Exhaustion, Depersonalization and Personal accomplishment

\begin{tabular}{|c|c|c|c|c|c|c|c|}
\hline \multirow[b]{2}{*}{ Model } & \multicolumn{2}{|c|}{$\begin{array}{l}\text { Unstandardized } \\
\text { Coefficients }\end{array}$} & \multirow{2}{*}{$\begin{array}{c}\begin{array}{l}\text { Standardized } \\
\text { Coefficients }\end{array} \\
\text { Beta }\end{array}$} & \multirow[t]{2}{*}{ Sig. } & \multirow[t]{2}{*}{$F$} & \multirow[t]{2}{*}{ Sig. } & \multirow[t]{2}{*}{$R 2$} \\
\hline & B & $\begin{array}{l}\text { Std. } \\
\text { Error }\end{array}$ & & & & & \\
\hline (Constant) & 6.98 & 1.40 & & .000 & & & \\
\hline $\begin{array}{l}\text { Emotional } \\
\text { Exhaustion }\end{array}$ & .235 & .085 & $.268^{* *}$ & .007 & $7.65^{* *}$ & .007 & .072 \\
\hline (Constant) & 18.63 & 1.88 & $.339^{* * *}$ & .000 & & & \\
\hline Depersonalization & .410 & .114 & & .001 & $12.83^{* * *}$ & .001 & .115 \\
\hline (Constant) & 45.99 & 1.78 & $-.233^{*}$ & .000 & & & \\
\hline $\begin{array}{c}\text { Personal } \\
\text { accomplishment }\end{array}$ & -.257 & .108 & & .019 & $5.67^{*}$ & .019 & .054 \\
\hline \multicolumn{8}{|c|}{ Note. Independent Variable: Challenge stressors } \\
\hline${ }^{*} p<.05$ & & & ${ }^{* *} p<.01$ & & & & ${ }^{* *} p<.0$ \\
\hline
\end{tabular}




\section{CONCLUSION AND RECOMMENDATIONS}

The main objective of this study was to examine the relationship between challenge stressors and burnout. Therefore, based on the results from correlation and single linear regression analyses, it can be concluded that challenge stressors are statistically proven to be a significant predictor of burnout in the context of female employees in the banking sector in Mongolia. It means that the challenge stressors are perceived to be a kind of negative stress that is more likely to lead the participants to feel emotionally exhausted and to demonstrate negative reactions against customers. This is consistent with the findings of the review paper carried out by Purvanova \& Muros (2010) and the study done by Behrman \& Perreault (1984), who proposed that employed females are more emotionally exhausted than employed males. Besides, the main result of this study is in line with Zapf et al. (1999), who suggested that emotional labor makes employees more exhausted psychologically. However, this overall finding is not consistent with the results of other key studies on challenge stressors that have been done by Cavanaugh et al., (2000); Boswell et al. (2004); Podsakoff \& LePine, (2005) and Podsakoff et al., (2007). According to them, employees perceive the challenge stressors as positive stress, which makes them satisfied, motivated, committed to their jobs, and pushes them to perform better.

Most interestingly, apart from the main finding of this study, among the three dimensions of burnout, personal accomplishment is found to have a significant and negative association with challenge stressors, which is in line with the findings of other main studies on challenge stressors such as Bhagat et al., (1985) and Cavanaugh et al., (2000). It means that if female workers in the banking sector feel more self-accomplished after getting familiar with the challenge stressors at workplaces, they may be able to be motivated and driven by the effects of the challenge stressors instead of feeling burnout or emotionally tired at workplaces. It may be explained in relation to Mongolian culture that is characterized as being high in individualism (Rarick et al., 2014) in terms of Hofstede's cultural assessment model. Individuals who belong to individualistic cultures can be a stable, independent self (Triandis, 1993). It indicates that achieving personal goals in society is more important to individuals. Hence, HR managers in the banking sector in Mongolia need to be fully aware of how to manage the challenge stressors among female employees using it as a motivational tool to make females to feel them not only self-accomplished but also not to reach burnout at the same time in the workplace of the $21^{\text {st }}$ century since the impact of the challenge stressors on burnout is found to be two-sided among the participants of this study. The limitation of this study can be the sample size. The data collected from 101 female employees in Mongolia may be insufficient. So, it is advisable to collect more data to ensure further statistical results.

\section{REFERENCES}

Boswell, W. R., Olson-Buchanan, J. B., \& LePine, M. A. (2004). Relations between stress and work outcomes: The role of felt challenge, job control, and psychological strain. Journal of Vocational Behavior, 64(1), 165-181.

Behrman, D. N., \& Perreault Jr, W. D. (1984). A role stress model of the performance and satisfaction of industrial salespersons. The Journal of Marketing, 48(4), 9-21.

Buiter, W., \& Rahbari, E. (2011). Global Growth Generators: Moving Beyond "Emerging Markets" and "BRIC". Citigroup Global Markets Global Economic View, 21.

Bingham, J.B., Boswell, W.R., \& Boudreau, J.W. (2005). Job demands and job search among high-level managers in the United States and Europe. Group \& Organizational Management, 30, 653-681.

Bhagat, R.S., McQuaid, S.J., Lindholm, H., \& Segovis, J. (1985). Total life stress: A multimethod validation of the construct and its effects on organizationally valued outcomes and withdrawal behaviors. Journal of Applied Psychology, 70, 202-214.

Brotheridge, C. M., \& Grandey, A. A. (2002). Emotional labor and Burnout: Comparing two perspectives of "people work". Journal of Vocational Behavior, 60(1), 17-39.

Cavanaugh, M. A., Boswell, W. R., Roehling, M. V., \& Boudreau, J. W. (2000). An empirical 
examination of self-reported work stress among US managers. Journal of Applied Psychology, 85(1), 65-74.

Cordes, C. L., \& Dougherty, T. W. (1993). A review and an integration of research on job burnout. Academy of Management Review, 18(4), 621-656.

Cohen, S., \& Janicki-Deverts, Denise. (2012). Who's Stressed? Distributions of Psychological Stress in the United States in Probability Samples from 1983, 2006, and 2009 1. Journal of applied social psychology, 42(6), 1320-1334.

Chathoth, P., Altinay, L., Harrington, R. J., Okumus, F., \& Chan, E. S. (2013). Coproduction versus co-creation: A processbased continuum in the hotel service context. International Journal of Hospitality Management,32, 11-20.

Davaasuren, V. (2015). The Northeast Asian Economic Review. Vol 3, № 2.

Diefendorff, J. M., Richard, E. M., \& Croyle, M. H. (2006). Are emotional display rules formal job requirements? Examination of employee and supervisor perceptions. Journal of Occupational and Organizational Psychology, 79(2), 273-298

Frey, C.B, \& Osborne, M.A. (2013). The Future of Employment: How Susceptible Are Jobs to Computerisation? the Oxford Martin Programme on the Impact of Future Technology, 2013 Working Paper No. 1. International Labour Organization. (2018). Report. Retrieved from https://www.ilo.org/global/about-theilo/newsroom/news/WCMS_627189/lang-en/index.htm. Assessed Jan 2020.

Greenberg, E. R., \& Canzoneri, C. (1996). Organizational Staffing and Disability Claims. NY: American Management Association Report-1996.-35 p.

Harari, Y. N. (2018). 21 Lessons for the 21st century. Random House.

Hochschild, A. R. (1983). The managed heart: Commercialization of human feeling. Berkeley, CA: University of California Press.

Hobfoll, S. E., \& Shirom, A. (2000). Conservation of resources theory: applications to stress and management in the workplace. In R. T.
Golembiewski (Ed.), Handbook of Organizational Behavior (2nd ed., pp. 5781). New York, Dekker

Ivancevich, J. M., \& Matteson, M. T. (1980). Stress and work: A managerial perspective. Scott Foresman.

Jargalsaikhan, D. 2019. "Fintech: like a bird in the hand". Retrieved from https://www.jargaldefacto.com/article/finte ch-like-a-bird-in-the-hand. Last Accessed: Jan 2020.

Janis, I., \& Alias, M. (2017). A systematic literature review: Human roles, competencies, and skills in industry 4.0. In Proceeding of Asia International Multidisciplinary Conference. pp. 10521072

Jex, S. M. (1998). Stress and job performance. Thousand Oaks, CA: Sage. Landis, R. S., Beal, D. J., \& Tesluk, P. E. (2000). A comparison of approaches to forming composite measures in structural equation models. Organizational Research Methods, 3, 186207

Kessler, R. C., McLeod, J. D., \& Wethington, E. (1985). The costs of caring: A perspective on the relationship between sex and psychological distress. In I. G. Sarason \& B. R. Sarason (Eds.), Social support: Theory, research, and applications (pp. 491-507). Boston: Martinus Nijhoff Markets" and "BRIC" (Global Economics View). Citigroup Global Markets.

Kim, H. J. (2008). Hotel service providers' emotional labor: The antecedents and effects on burnout. International Journal of Hospitality Management, 272), 151-161.

Kruml, S. M., \& Geddes, D. (2000). Exploring the dimensions of emotional labor: The heart of Hochschild's work. Management Communication Quarterly, 14(1), 8-49.

LePine, J.A., Podsakoff, N.P., \& LePine, M.A. (2005). A meta-analytic test of the challenge stressor-hindrance stressor framework: An explanation for inconsistent relationships among stressors and performance. Academy of Management Journal, 48, 764-775.

Marshall, N. L., \& Barnett, R. C. (1993). Work-family strains and gains among two-earner couples. Journal of Community 
Psychology, 21(1), 64-78.

Maslach, C., \& Jackson, S. E. (1981). The measurement of experienced burnout. Journal of Organizational Behavior, 2(2), 99-113

Marshall, N. L., \& Tracy, A. J. (2009). After the baby: Work-family conflict and working mothers' psychological health. Family Relations, 58(4), 380-391.

Maslach, C., Jackson, S. E., \& Leiter, M. P. (1996). MBI: Maslach burnout inventory. Sunnyvale (CA): CPP, Incorporated.

Maslach C, Schaufeli WB, \& Leiter MP. Job burnout. Annu Rev Psychol. 2001; 52(1):397-422.

Millier, K, \& Bellamy, P. J. (2014). The Business Women's Association of Uzbekistan: A qualitative study of the emergence and potential influence of women's leadership in Central Asia. Journal of Eastern European and Central Asian Research (JEECAR), 1(1), 10-10.

National Statistical Office of Mongolia [NSOM], (2019). Mongolian statistical yearbook. Retrieved from http://www.nso.mn/. Accessed Jan 2020.

National Statistical Office of Mongolia [NSOM], 2020). Retrieved from www.1212.mn. Accessed June 2020.

Neugebauer, R., Hippmann, S., Leis, M., \& Landherr, M. (2016). Industrie 4.0 - From the Perspective of Applied Research. Procedia CIRP, 57, 2-7.

Our World in Data. (2017). Online publication. Retrieved from https://ourworldindata.org/search?q=femal e+labor+participation+rate. Accessed Jan 2020.

Podsakoff, N. P. (2007). Challenge and hindrance stressors in the workplace: Tests of linear, curvilinear, and moderated relationships with employee strains, satisfaction, and performance (Doctoral dissertation, University of Florida).

Podsakoff, N. P., LePine, J. A., \& LePine, M. A. (2007). Differential challenge stressorhindrance stressor relationships with job attitudes, turnover intentions, turnover, and withdrawal behavior: a meta- analysis. Journal of Applied

Psychology, 92(2), 438-454.

Purvanova, R. K., \& Muros, J. P. (2010). Gender differences in Burnout: A metaanalysis. Journal of vocational behavior, 772), 168-185.

Rodell, J. B., \& Judge, T. A. (2009). Can "good" stressors spark "bad" behaviors? The mediating role of emotions in links of challenge and hindrance stressors with citizenship and counterproductive behaviors. Journal of Applied Psychology, 94(6), 1438.

Rarick, C., Winter, G., Barczyk, C., Pruett, M., \& Nickerson, I. (2014). Mongolia: A cultural portrait using the Hofstede 5-D model. Global Journal of Management and Business Research.

Sarason, I.G. \& Johnson, J.H. (1979). Life stress, organizational stress, and job satisfaction. Psychological Reports, 44, 75-79.

Scheck, C.L., Kinicki, A.J., \& Davy, J.A. (1995). A longitudinal study of a multivariate model of the stress process using structural equation modeling. Human Relations, 48, 1481-1510.

Scheck, C.L., Kinicki, A.J., \& Davy, J.A. (1997). Testing the mediating processes between work stressors and subjective well-being. Journal of Vocational Behavior, 50, 96-123.

Taylor, P., \& Bain, P. (1999). 'An assembly line in the head': work and employee relations in the call centre. Industrial relations journal, 30(2), 101-117.

Triandis, H. C. (1993). Collectivism and individualism as cultural syndromes. Crosscultural research, 27(3-4), 155-180.

Veresné Valentinyi, K. (2015). A terminológiamenedzsment oktatása tömörítve. PORTA LINGUA: 21 pp. 169-187., 19 p. (2015)

Wang, L., Törngren, M., \& Onori, M. (2015). Current status and advancement of cyberphysical systems in manufacturing. Journal of Manufacturing Systems, 37, 517-527.

World Economic Forum: Market Projections: The future of jobs reports 2018 summary. Retrieved from https://www.gqrgm.com/market- 
projections-future-jobs-report-2018summary/. Accessed 10 March 2020.

Yagil, D. (2008). When the customer is wrong: A review of research on aggression and sexual harassment in service encounters. Aggression and Violent Behavior, 13(2), 141-152.

Yu, C., Xu, X., \& Lu, Y. (2015). Computerintegrated manufacturing, cyber-physical systems, and cloud manufacturing-concepts and relationships. Manufacturing Letters, 6 , 5-9.

Zapf, D. (2002). Emotion work and psychological well-being: A review of the literature and some conceptual considerations. Human Resource Management Review, 12(2), 237268.

Zapf, D., Vogt, C., Seifert, C., Mertini, H., \& Isic, A. (1999). Emotion work as a source of stress: The concept and development of an instrument. European Journal of Work and Organizational Psychology, 8(3), 371-400.

\section{ABOUT THE AUTHORS}

Tumentsetseg Enkhjav, email: tumee5332@gmail.com

Mr. Tumentsetseg Enkhjav is a PhD student at Doctoral School of Business Administration and Management, Szent Istvan University, Hungary.

Dr. Csehné Papp Imola is an Associate Professor at the Institute of Research on Adult Education and Knowledge Management, Eötvös Loránd University, Hungary

Dr. Erika Varga is an Associate Professor at the Institute of Foreign Languages at Szent István University, Hungary. 